\title{
Correction to: Organochlorine Chemical Residues in Northern Cardinal (Cardinalis cardinalis) Eggs from Greater Washington, DC USA
}

\author{
Christopher J. Schmitt ${ }^{1}$ (D) Kathy R. Echols ${ }^{1} \cdot$ Paul H. Peterman ${ }^{1} \cdot$ Carl E. Orazio $^{1} \cdot$ K. Christiana Grim $^{2} \cdot$ Shirlee Tan $^{2,3}$. \\ Nora E. Diggs ${ }^{4} \cdot$ Peter P. Marra ${ }^{4}$
}

Published online: 3 July 2018

(c) Springer Science+Business Media, LLC, part of Springer Nature 2018

\section{Correction to: \\ Bulletin of Environmental Contamination and Toxicology (2018) 100:741-747 \\ https://doi.org/10.1007/s00128-018-2357-x}

The original version of this article contained a mistake. Author name in the text citation and reference in section should be Maldonado et al (2016), it was incorrectly spelled as Maldinado et al (2015).

The corrected correct text citation and reference are given below:
Maldonado et al (2016).

In page 743, first paragraph, last sentence, the word "shell thickness" should be deleted.

\section{Reference}

Maldonado AR, Mora MA, Sericano JI (2016) Seasonal diff erences in contaminant accumulation in neotropical migrant and resident songbirds. Arch Environ Contam Toxicol 72:39-49

The original article can be found online at https://doi.org/10.1007/ s00128-018-2357-x.

Christopher J. Schmitt cjschmitt@usgs.gov

1 Columbia Environmental Research Center, U.S. Geological Survey, 4200 New Haven Road, Columbia, MO 652011, USA

2 Center for Species Survival, Smithsonian National Zoological Park, Front Royal, VA, USA

3 Present Address: Public Health Seattle and King County, 401 5th Ave., Seattle, WA 98104, USA

4 Smithsonian Migratory Bird Center, National Zoological Park, 3001 Connecticut Avenue NW, Washington, DC 20008, USA 